\title{
The Concept of NEO Theater Performances: Appreciation for Acting
}

\section{\& THEATREREVIEW}

jurnal tari, teater, dan wayang volume 1 number 2 ,

November 2018

page $76-83$

\author{
Tatang Abdullah \& Ipit Saefidier Dimyati ${ }^{1}$ \\ Department of Theater, Institut Seni Budaya Indonesia (ISBI) Bandung
}

\begin{abstract}
This research investigates NEO Theatre (NT) by using historical approach. It has several significances; i.e. firstly, NT is one of modern theater groups that influences modern theater development in Bandung; secondly, though it is still relatively new, the creativity of NT cannot be separated from the history of Fathul A. Husein's creativity development as its director. By applying method of history through several stages from heuristics, critics, interpretation, to historiography; NT's creativity pattern can be constructed; it is in accordance with the aim of this research, to achieve the historical illustration of NT's creativity pattern in realizing the prototype of theater performance entitled Tritik Segaris Putih. Fathul A. Husein, as the NT leader, was one of the founders of theater Actors Unlimited (AUL) established in mid 1990s. Having it ended, Fathul A. Husein, who acted more as a director, founded NT on 18 April 2012. Based on the works Fathul directed since his time in AUL, the creative process of NT shows similar creativity with the Studiklub Theater Bandung (STB). An important fact to support this statement is that as a modern theater observer and critic, Fathul had ever joined in some productions of STB during the time of Suyatna Anirun (RIP) before he decided to join in the founding of AUL. Thus, it can be said that the model of STB theater creativity pattern is also reflected on the creativity pattern of NT in each of its theater production.
\end{abstract}

Keywords: theater history; theater production; NEO Theater

\begin{abstract}
Abstrak
Penelitian ini menyelidiki NEO Theatre (NT) dengan menggunakan pendekatan historis. Ini memiliki beberapa signifikansi; yaitu, pertama, NT adalah salah satu kelompok teater modern yang mempengaruhi perkembangan teater modern di Bandung; kedua, meskipun masih relatif baru, kreativitas NT tidak dapat dipisahkan dari sejarah pengembangan kreativitas Fathul A. Husein sebagai direkturnya. Dengan menerapkan metode sejarah melalui beberapa tahapan mulai dari heuristik, kritik, interpretasi, hingga historiografi; Pola kreativitas NT dapat dibangun; Ini sesuai dengan tujuan penelitian ini, untuk mencapai ilustrasi historis pola kreativitas NT dalam mewujudkan prototipe pertunjukan teater berjudul Tritik Segaris Putih. Fathul A. Husein, sebagai pemimpin NT, adalah salah satu pendiri teater Actors Unlimited (AUL) yang didirikan pada pertengahan 1990-an. Setelah itu berakhir, Fathul A. Husein, yang bertindak lebih sebagai sutradara, mendirikan NT pada 18 April 2012. Berdasarkan karyakarya yang diarahkan Fathul sejak di AUL, proses kreatif NT menunjukkan kreativitas serupa dengan Teater Studiklub Bandung (STB). Fakta penting untuk mendukung pernyataan ini adalah bahwa sebagai pengamat dan kritikus teater modern, Fathul pernah bergabung dalam beberapa produksi STB selama masa Suyatna Anirun sebelum ia memutuskan untuk bergabung dalam pendirian
\end{abstract}

$1 \quad$ Correspondence: Department of Theater, Institut Seni Budaya Indonesia (ISBI) Bandung. Jln. Buah Batu 212 Bandung. E-mail: tatang_abdullah@yahoo.com. HP: +62818226809 
AUL. Dengan demikian, dapat dikatakan bahwa model pola kreativitas teater STB juga tercermin pada pola kreativitas NT dalam setiap produksi teaternya.

Kata kunci: sejarah teater; produksi teater; NEO Theater

\section{Introduction}

NEO Theater, with its relative short existences, has high level of production. This is highly influenced by the work of Fathul A. Husein as both observer and actor. Since he joined Studiklub Teater Bandung (STB) followed by establishing a theater group named Actors Unlimited in 1999, his work as a director is highly valued by modern teather observers in Bandung and Jakarta.

As a developing teather group, his actors owned _ and _ experienced in reviving various text from this country written by many famous writers. The works of AUL teather lay on a stage where they try to communicate imaginative world with the real one. This effort seems to succeed, proven by high enthusiasm of audience attending their performances. Besides, several critics also wrote their reviews. Some of the reviews were published on national newspapers and magazines, such as Tempo magazine, Koran Tempo, Kompas, Pikiran Rakyat, and Media Indonesia newspapers. In addition, AUL teather is the only teather in Bandung that is able to post advertisements on Tempo magazine and Koran Tempo newspaper when their performance will be on stage (Maulana, 2004: 40).

In order to maintain their performance quality, AUL tried many ways to make it succeed. Their performance is not a kind of sensual teather; instead they are able to create spiritual experience. Many of human interests are released to reach the spiritual aspect. Sometimes, they need to sell their belongings only for the sake of theatre (Sumardjo, 2004: 24).

In the era of STB (1972-2002) led by Suyatna Anirun who also acted as its motivator, the role of actors as the performance center was not only seed from their skils but also from their humanistic aspect. Eka Gandara
WK (a senior actor of STB) convinced that Anirun gave an understanding about how an actor is required to possess intellectuality, intelligence, and spiritual experience (Abdulla, 2015: 157). This understanding highly influenced to their creativity pattern, both in AUL and NT. Therefore, it can be said that NT is a teather group that, according to Anirun, has been 'Humanized Ideas on Stage". This jargon, created by Anirun, that means honoring acting on stage impressed Fathul a lot in producing his teather production, both in AUL and NT.

At the time when AUL no longer acted on stage, through its spirit and teather spirit developed in AUL principles, Fathul established NT on April 18, 2012. NT was established in the middle of theater group existence crisis related to its creative process. Thus, it is important to emphasize the study of teather development by reviewing their efforts to survive in existence crisis (an interview result with Fathul in July 25, 2016 in ISBI Bandung). The method applied in this study is a history method consisting of heuristics, critics, interpretation, and historiography (Garraghan, 1957: 33; Gottschalk, 1975: 35-36; Herlina 2008; 10).

At heuristic level, both primary and secondary sources from either oral or written texts are employed to obtain information on the creativity concept of Fathul A. Husein as a director of AUL and NT. Some sources are reviews written by teather observers published in mass media, review, and critics of teather productions by AUL and NT.

The primary sources of oral data gained by conducting an interview with teather actors on July 25, 2016 in Staffroom of Teather Program, ISBI Bandung. This step was conducted after searching and collecting many written sources, either primary or secondary. The tangible sources (pictures or audio-visual recordings) of teather performances were also used to support this research. 
The step of critics was then followed by interpretation. This both stages were conducted directly by reading sources resulted from heuristic stage. It is due to the fact that either the actors and teather groups are still alive and exists at the time of this research (verification/ critics and interpretation) to those sources by doing direct interview with those actors. By using this direct interview technique, it is possible to reach the validity and credibility of those sources.

The last stage is historiography. This stage is a writing stage that requires art of writing skill (Garraghan, 1957: 34; Gottschalk, 1986: 143; Kuntowijoyo, 1995: 89-105). In other words, in this stage, the result of imaginative reconstruction on NT's creativity pattern should be report chronologically based on valid and credible sources as a prototype of STB's creativity pattern model. This creativity pattern has been revealed through performing a teather work entitled with Tritik Segaris Putih.

\section{The History of NT}

The story of the founding of NT on April 18, 2012 was related to one of NT's founders, Fathul, who was once a teather activist joining two teather groups, STB and AUL. At the beginning of 1990s, he often help STB's performances, either as an actor or as a writer of appreciation introduction before STB's performances. In 1999, after STB had performed Art by Yasmine Reza, a senior member of STB, Yoyon Sunjaya and some other juniors agreed to found another new group named AUL.

Having repeatedly directing AUL's performances, Fathul seemed to feel unsatisfied with the group. Then, after joining the AUL for thirteen years, he established a new teather group, named NT. The initial performance of NT, Kembara Kelam, was adapted from a realism work of American writer, Eugene O'Neill, entitled with Long Day's Journey into Night. The work was translated by Indrie Setya Lestari. On April 18, 2012, the performance became the day of NT's founding. However, Fathul stated that the actual background of founding NT showed up when he had a casual discussion with his partners, Herry Dim and Agus R. Sarjono in the Lecturer Room of Theater Department, ISBI Bandung in 2010. During the discussion, there were some concerns expressed related to the situation and condition of the problems faced by theater groups to maintain their existence and creative processes. Government was also nearly absent in providing any social, economic, or political supports towards theater arts. Instead, the government provided greater support to any "event" arts, like tourism arts. In Fathul and Sarjono's opinions, it was needed some theater groups who are able to survive and exist in that really difficult and impossible situation. Meanwhile, Dim proposed a question about the future of theater history without any existence of theater groups who faced difficulties in maintaining their existence. Further, Fathul explained in an interview ${ }^{2}$ that the name of NEO Theater has appeared. The name refers to a 'new' (neo) thing and carries a simple meaning: a never-giving up "new spirit" is required to endure the history of theater.

The word "NEO" was written all in capitals as, in Fathul's mind, it is meant to be an acronym, thought its complete meaning remains a secret by Fathul. The meaning itself will be revealed when NT is able to survive for ten years. Among many performances of NT until recent time are:

1. Kembara Kelam, adapted from Eugene O'Neill's work entitled with Long Day's Journey into Night. The work is based on a translation by Indrie Setya Lestari, and directed by Fathul A. Husein (2010).

2. Klitemnestra, a work of Tadasi Suzuki, translated and directed by Fathul A. Husein.

3. Keburan Laut, a work of John M. Singe, translated and directed by Fathul A. Husein.

4. Kali, a work of Goenawan Muhammad, translated and directed by Fathul A. Husein. The work was performed in form of dramatic reading.

5. Oedipus, a work of Andre Gide, directed by Fathul A. Husein.

6. Tritik Segaris Putih, taken from a work of August Strindberg entitled with Facing 
Death. The work is translated, adapted, and directed by Fathul A. Husein.

\section{Theatrical Concept of NEO Theatre}

On the logo of NT, there was a slogan ' $E x$ ploring New Paradigms'showing a meaning of an effort to seek out a relatively new paradigm in the theater process as manifested in NT's performances. The use of capital letters in its name also seems to suggest any possibilities in making such effort as its main purpose.

Principally, NT initiated its basic principle like past theaters that regarded actor as the main media of a theater. It means that in theater, NT tried to regard acting as the principal element in a theater existence, by employing dramatic texts as its starting point. Thus, NT theater is a theater that honors acting as its basis of existence. Likewise, an understanding on this new paradigm intended to be the principle is to form NT as a learning theater. As a learning theater, NT tried to explore undiscovered areas of acting due to some rea-
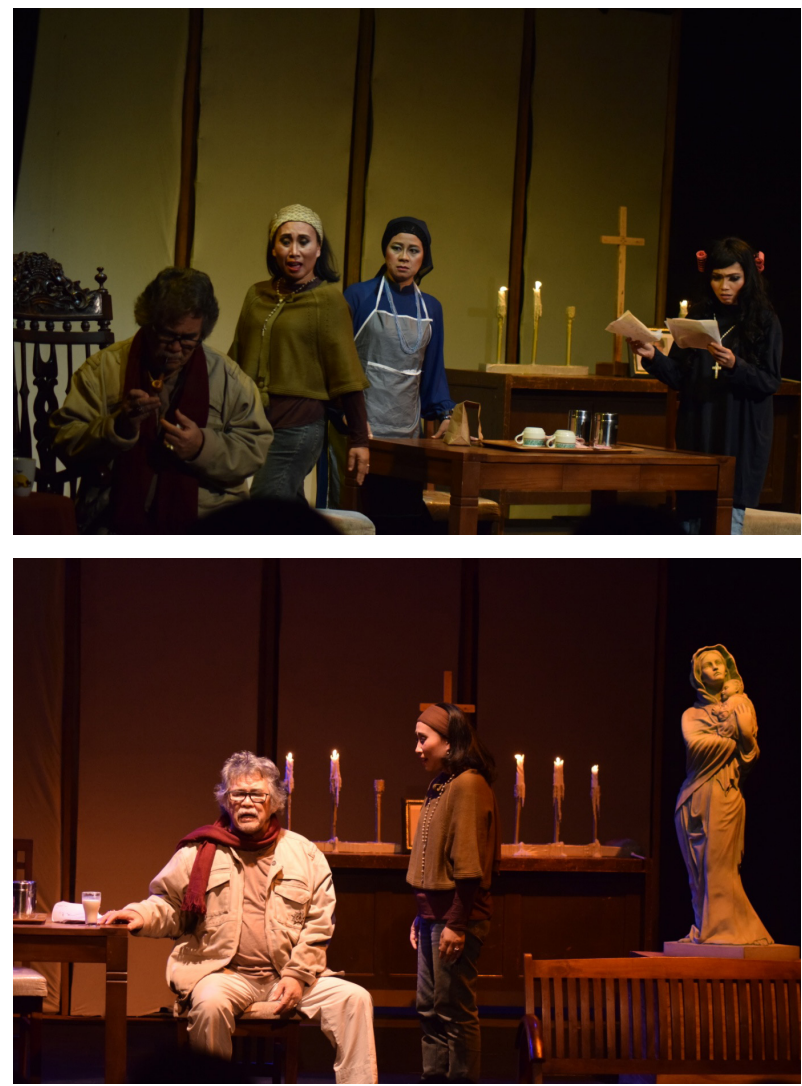

Figure 1. A theater performance of NT entitled with Tritik Segaris Putih. The original title of the work is Facing

Death, written by August Strindberg. It was translated, adapted, and directed by Fathul A. Husein. It was the sixth performance of NT. (Photo: Firdaus Muhammad)

sons, such as lack of references or knowledge about those areas. If it is possible, NT expects to perfect some late good achievements. In addition, the paradigm of performing to achieve is a performance showing some effectivity and interrelation with other subjects or arts, such as arts philosophy and semiotics.

The vision of NT 'Exploring New Paradigms' seems to provide a logical consequence to NT's works: to fix some flaws in the theater world. The flaws were due to lacks of good yet challenging play scripts to be acted, either plays written by national authors or translated and adapted scripts written by foreign authors. As compared to the growing number of theater groups in Indonesia as well as educational institution of theater arts, the number of good play scripts is only a few.

To solve the problem, it is necessary to translate and adapt new play scripts. Besides, it is also important to increase the number of previously translated or adapted well-wrtitten play scripts. Other efforts include widening some perspectives on excellent reasonings
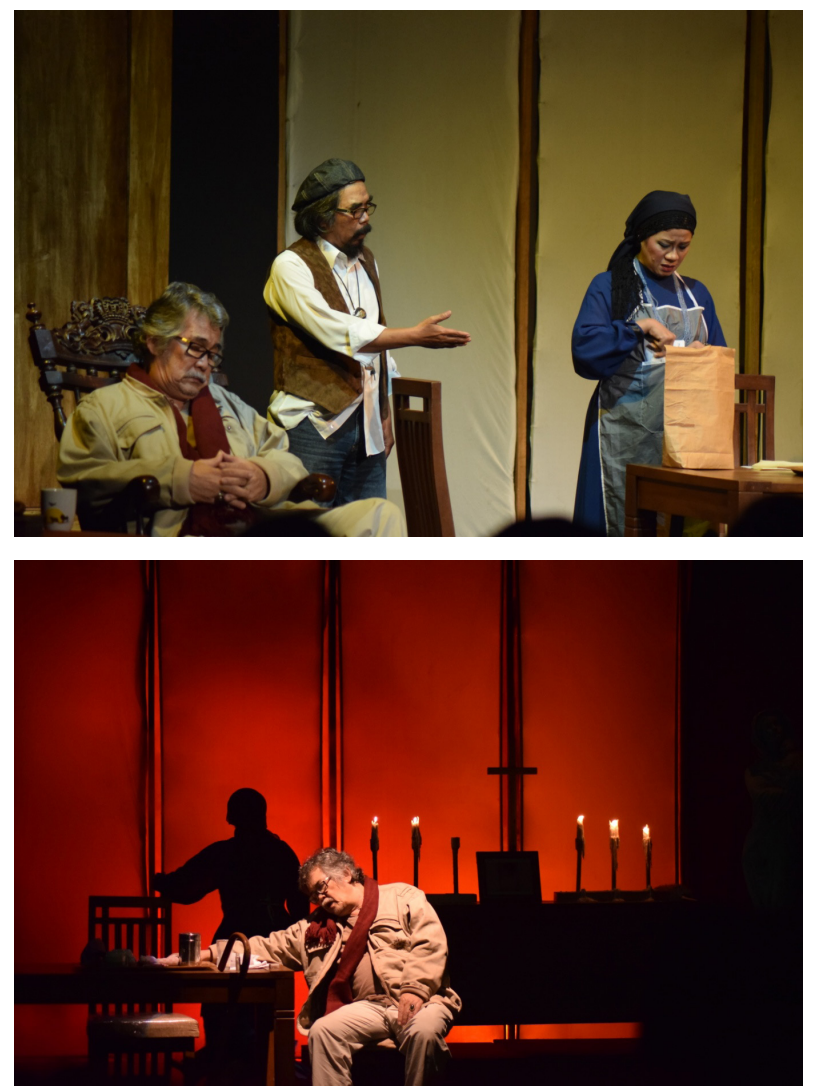
about multi-dimension of humanity and human life through thematic and philosophical approaches expressed by famous play writers and scholars in their works. Those efforts are important since not every actor or director can work as a play writer.

In fact, the theater concept of NT is almost similar to AUL's concept, a group of theater in which Fathul has ever joined. AUL was based on the philosophy of "actors who overcome the limit." Its main objective is, similar to NT, to honor acting. "Overcoming limit" means that actors should push their creativity to their limits in order to reveal their potention in acting. Fathul (2004: 200), in his writing for the introduction of Suara-suara Mati written by Manueal Van Loggem, stated that among any others, creative works - the basic of art works - are attempts to do a perpetual search, a limitless exploration. The creativity is expressed in a spirit of constant innovation without any stagnancy, a spirit to try new things through ups and downs. The risk from such spirit is to find a new thing or even the search itself. Further, Fathul also mentioned that the basic principles of AUL and NT are similar since they were founded from the same principle, i.e. to develop the spirit of theater as the basis of studying, learning, and discussing based on the experiences and knowledge of their members. He also acknowledged that such spirit was gained from STB who held its principle firmly: "An honest loyalty should always be improved." In his opinion, an honest loyalty means that creativity within a pure spirit should ask less and sacrifice more. He claims that, "the difference among STB, AUL, and NT lays merely on technical issues, such as how to manage the organization. However, the history of NT has not been corroborated that it could not be compared to the creative processes of either STB or AUL."

Any discussions pertaining to STB cannot be separated from the figure of Suyatna Anirun, the one who often directed most performances of STB. Fathul claims that Anirun gave strong influence to himself that he learned not only from books, essays, or people's opinions but also from other sources, either academic or real experiences about theater performances. $\mathrm{He}$, though, acknowledges that he met Anirun for quite a short time, only few years; yet Anirun's idea about honoring actors on stage seems to have a deep impact on his own creative process. The attitude of Anirun that firmly held his principle that an actor is actually the principle medium of a theater is also consistently applied by Fathul in directing his theater performances.

A theater oriented to the actors as its performance center is usually presented in theatrical performance based on a drama play with fine dramatic elements. Intrinsically, the play script has some elements in it; such as plot, characters, dialogues, theme, or other explicit dramatic structures. Therefore, when proposing a play script to be performed by NT, Fathul uses those intrinsic elements as the main criteria in choosing a right play. Fathul argues that dramatic qualities are the main requirements in creating a great challenge for achieving performing arts. A dramatic quality may appear in a work of play due to some conflicts resulted from a unique point of view as well as the author's intelligence in creating a theme critically and philosophically. It is when a play script is considered to fulfil all those requirements that Fathul will decide it as the script for NT's performance. Though some problems, such as theme relevance with the real situation and condition during a performance, could be ignored. Fathul claims that a script's relevance should be viewed more on its humanity insight rather than on its relevance with the present condition. A script can be considered to have universal values and to be actual in every situation when it shows a serious insight and is critical to humanity issues. He further added that:

"Whenever I found a play full of dramatic quality as well as deep in philosophical values, I'll be readily eager to perform it. As for its thematic actuality - that a play should be actual with the present situation is no longer important, since I believe that any good effort of giving an insight to humanity, anytime and anywhere will create a 
universal value, in terms of that it will be an actual work."

In other words, Fathul's belief on humanity values is beyond time and space, as it is in accordance with universal humanism - a valuable artwork is to be able to reverberate in any situation. Instead of being created to serve such a political or group interest, a work of arts is created based on pure desire of creation. In the view of universal humanism, an artist is someone who is gifted with his sensitivity to capture 'eternity' in a world of temporariness.

Once a play script has been chosen, the next step is to choose the actors. As a group that chooses its actors based on its important role in succeeding the work of a theater performance, NT usually works with actors who no longer struggle with the basic matters of acting - such as vocalization, articulation, stage entrance techniques, body language, and role appreciation. As a director, Fathul in selecting his actors - chose to believe in his faith on the actors who are considered to have good and proper abilities in acting their roles. He strongly believes that any prior uncertainty may lead to a consequence when actors cannot appreciate the essence of the play; this can result in the failure of the director to interpret the concrete stage form.

Nevertheless, there are some times when the ideal condition in performing a play with expected actors could not be achieved. Some actors are no longer active in theater because

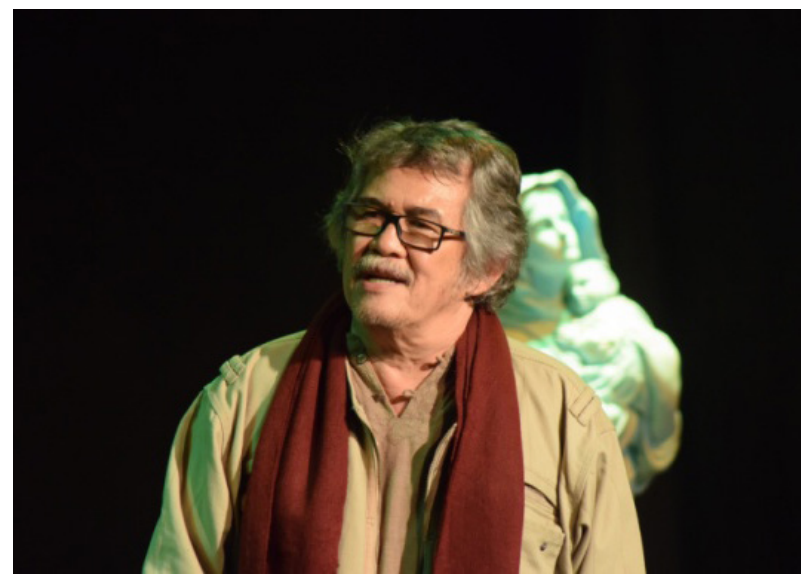

Figure 2. A senior actor of STB, Eka Gandara WK played as Kartawijaya, a character in the play performance of "Tritik Segaris Putih", directed by Fathul A. Husein. (Photo: Firdaus Muhammad) of different reasons, such as being enjoined by their spouses, working in certain institutions, or having some health issues. In order to anticipate those matters, Fathul usually appoints some substitute actors. But in reality, the real challenge lays on an actor's creativity instead of actor selection. Thus, Fathul also holds a principle that he actually works with real actors instead of with those who learn to be actors.

". . . whoever the actors are, either seniors or juniors, they have to be sure that they themselves are actors, thus they have to be responsible with their acting."

One of a director's responsibilities covers transferring ideas. It is related to how to communicate every of performing idea to its supporters. Such communications, however, often do not run well due to different perceptions or understanding among those people, similar to what happens to Fathul. Thus, he tried to propose the best way for expressing his ideas as a director. He argues that the first important thing in expressing an idea is to choose proper dictions; in other words, he needs to choose a proper language to communicate. Since not everyone can understand ideas in theater expressed using complex language or vice versa, it is important to use diction that is appropriate with the situation an condition of the communicators to ensure that the communication can run well and the message

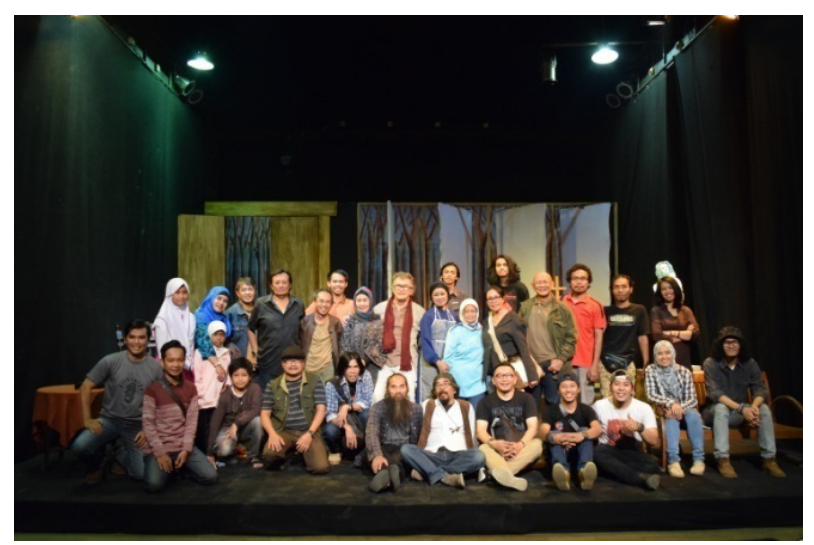

Figure 3. A picture taken after a performance. It shows the play director, actors, artistic crews and manager, critic, senior actors and actresses of STB expressing their happiness upon the success of the performancen. (Photo: Firdaus Muhammad) 
conveyed can be well understood.

In communicating to the supporters of NT performances, Fathul usually conveys several matters, i.e.:

1. The essence and substance of the play;

2. The view and criticism of the director towards the play, such as the play's strengths and weaknesses, the director's favored and disfavored parts, and interesting parts;

3. The concept of performance, such as explaining about parts that should be featured and parts that can be neglected;

4. The artistic concept and pre-stage cost;

5. The creativity of the supporters, especially the actors by testing them to express their ideas and imaginative thought;

6. The decision of the director to apply a concept as the super-objective from all the performances.

In interpreting a playscript as a basis of a performance, Fathul usually asks someone or more to be in the position of dramaturge. This person is regarded as having broad knowledge and is wise in his thought. A dramaturge is needed since Fathul requires a sparing partner to test his arguments and views in analyzing a playscript, essentially in interpreting the deepest essence of the script itself. In the discussions with the dramaturge, Fathul usually stands on his own perspective regardless his partner of discussion proposes relatively different interpretation. It is during such discussions that Fathul is being assured on his own interpretation while many alternatives proposed by the dramaturge.

Nonetheless, Fathul does not merely ignore any suggestions proposed to him. Actors, artistic managers, or other performance supporters may come with their own abilities and thoughts that can be discussed to firm the concept and strategies of a performance. Therefore, a director is required to possess an ability to discover and explore those great knowledge and experiences; yet, he must also be able to hold the control. Those valuable experiences should be managed in the main frame of the performance in accordance with the initial concept of the director. Further, Fathul also asserts:
"Do not let any small element escaped from our hands and thus ruins all strategic concept (mise en scene) of the performance. In this situation, our confidence as a director is being questioned. For example, do not let a supporter, even a senior one, say freely: 'I suggest this part to be acted this or that way.' Create a situation where we can explore their depths through an interrelation that is based on our inner depths and avoid any intersubjective conceptual debates. It is useless and endless. Convince them that any performance should be directed into a superobjective one, and that the director himself holds such a superobjective."

\section{Conclussion}

The creative process of NT under Fathul's direction can be concluded as below: NT is based on a theater principle that actor is the main medium of a theater. Therefore, a theater performance should portray how actors are being appreciated on stage. To realize the principle of actor appreciation, a play script with highly dramatic values. When such a script does not exist, it is a director's responsibility to find and translate one. The issue when a script is considered to be lessrelevant with recent condition is not the main problem. It is due to the value of a script and its noble philosophical values that, in common situation, exist in an eternal time and space. Accordingly, a script under that condition is considered to be an actual one.

To realize a script having dramatic values and qualities to be well performed, it is needed experienced actors, instead of actors who are still learning. However, when a problem happens while selecting actors, Fathul will take substitute actors under a condition that they are certain that they are able to play their roles. To communicate ideas of a script and its performing concept, a director realizes that a proper language is needed in order to avoid any misunderstandings. A proper language is important since every actor has their own level 
of perception and understanding that differs one to another. Any alternative discourses, either about the script or its superobjective performance, will be accepted as valuable suggestions. Nonetheless, the director as the main interpreter of the scripts is the one who are mostly responsible with the importance of the performance, and therefore, should be consistent in maintaining the concept of the performance.

\section{References}

Abdulah, Tatang \& Ipit S. Dimyati. (2015). "Dinamika Teater Modern di Bandung 1958-2002" Jurnal Panggung, Vol.25 No. 2 Juni 2015.

Garaghan, Gilbert J. (1946). A Guide to Historical Method. New York: Fordham University Press.

Gottschalk, Louis. (1975). Mengerti Sejarah,
Terjemahan Nugroho Notosusanto. Jakarta: Yayasan Penerbit Universitas Indonesia.

Herlina, Nina. (2008). Metode Sejarah. Bandung: Satya Historika.

Husein, Fathul A. (2004). "Tiada Gading Yang Tak Retak". dalam Fathul A. Husein dan Diyanto (Eds). Lima Tahun Pertama Actors Unlimited 1999-2004 Lima Tahun Pertama Actors Unlimited 1999-2004. Bandung: Batic Press.

Maulana, Soni Farid. (2004). "Actors Unlimited dan Kisah Sebuah Motor". dalam Fathul A. Husein dan Diyanto (Eds). Lima Tahun Pertama Actors Unlimited 1999-2004. Bandung: Batik Press.

Sumardjo, Jakob. (2004). "Pengalaman Dengan Actors Unlimited". dalam Fathul A. Husein dan Diyanto (Eds). Lima Tahun Pertama Actors Unlimited 1999-2004. Bandung: Batik Press. 